$\frac{\overline{\text { 原 } \text { 著 }}}{\text { 順天堂医学 } 36(4)}$

P. $517 \sim 526$ (1991)
モルモット単一心室筋におけるアデノシンの

カルシウムチャネル電流抑制の機序

\title{
Mechanism of depression of calcium channel current by adenosine in guinea-pig ventricular cells
}

\author{
加 藤 理* \\ МАкото KATO, M.D.
}

\begin{abstract}
アデノシン（Ado）の $\mathrm{Ca}^{2+}$ チャネル電流抑制の機序を解明する目的でモルモット単一心室筋細 胞汇細胞接着型パッチクランプ法を行い, 単一 $\mathrm{Ca}^{2+}$ チャネル電流を記録した。電極は $50 \mathrm{mM}$ ある いは $100 \mathrm{mM}-\mathrm{Ba}^{2+}$ を含 むものを使用した. $\mathrm{Ca}^{2+}$ チャネル電流の平均電流は, $100 \mathrm{nM}$-イソプロテ レノール（ISO）で対照の 2〜3 倍まで増加したが，0.1mM-Ado の潅流液中への添加で対照レべ ルまで減少した.乙の一連の変化は $1000 \mathrm{nM}-\mathrm{BAY}$ K8644 存在下でも認められた. チャネルの開孔 を含む掃引の割合（利用可能性 Ps）は ISO で増加し, Ado は乙れを減少した（対照 0.29土 0.09 ; ISO $0.62 \pm 0.13$; Ado および ISO $0.37 \pm 0.15$; 平均 \pm S. D. 5 例). $\mathrm{Ca}^{2+}$ チャネル電流 を含む掃引でみた開確率（Po）はほとんど影響をうけなかった（対照 $0.08 \pm 0.06$ ； ISO 0.08土 0.06 ; Ado および ISO 0.06士0.03). BAY K8644 存在下で求めた単一 $\mathrm{Ca}^{2+}$ チャネルコンダク タンスは約 $24 \mathrm{pS}$ で, ISO およびAdo に影響されなかった。 チャネル利用可能状態の平均持続時間は ISO で増加し, Ado の添加で減少した。一方, チャネル非利用状態の平均持続時間は ISO で減少 し, Ado の添加で増加した. 以上より, Ado はチャネルの遅いゲート過程を修飾しチャネル利用 可能性を減少するととにより, $\mathrm{Ca}^{2+}$ チャネル電流を抑制すると結論された。
\end{abstract}

索引用語：カルシウムチャネル, アデノシン, 心筋

Key words : calcium channel, adenosine, cardiac muscle

\section{緒言}

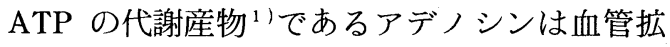
張作用ばかりでなく, 種々のレベルで心機能に影 響する.たとえば, 洞房結節の歩調取り機能・房 室結節の伝導, および $\beta$ アドレナリン性刺激下で の心室ポンプ機能を抑制する²!.乙れらのうち,

\footnotetext{
* 順天堂大学医学部循環器内科学講座

Division of Cardiology, Department of Internal Medicine, Juntendo University School of Medicine, Tokyo, Japan
}

〔Nov. 13, 1989 原稿受領〕（Dec. 21，1989 掲載決定）
陰性変周期作用, 陰性変伝導作用はカリウムチャ ネルのコンダクタンスの増加による ${ }^{3 !}$. 一方, 心 室筋への陰性変力の作用は, サイクリック AMP の減少を介したカテコラミンで増加した内向き $\mathrm{Ca}^{2+}$ 電流の減少 による(1) 6). さらにモルモット 心房筋で, アデノシンは基礎的 $\mathrm{Ca}^{2+}$ 電流をほと んど減らさないといわれる7!。れらのアデノシ ンの アデニールサイクラーゼ活性抑制作用, お了 よび収縮力抑制作用 ${ }^{8}$ はテオフィリンにより抑制 され, 膜のプリンレセプター（P 1 ）にアデノシ ンが結合して起てるとされている119).

本研究はアデノシンの単一 $\mathrm{Ca}^{2+}$ チャネル電流 への影響を調べることを目的とした．実験はイソ 
プロテレノールの存在下で行い, アデノシンの $\mathrm{Ca}^{2+}$ チャネル電流を含む掃引中の開確率 $(\mathrm{Po})$, および利用可能性 (Ps)への作用について解析し た.

\section{方法}

単一心室細胞は成熟モルモット心室筋より単離 した10).すなわち, モルモットを塩化ペントバル ビタール $(500 m g / k g)$ で麻酔し, 人工呼吸管理 下で心臓を摘出し, 以下の溶液を用いて順次 Langendorff 潅流を行った. 溶液は正常 タイロード 溶液・ $\mathrm{Ca}^{2+}$-free タイロード溶液・コラゲナーゼ 溶液 $(10$ 分〜20分 $)$ ・高力リウム・ $\mathrm{Ca}^{2+}$-free $(\mathrm{Kr}$ aftbruhe, KB）溶液の順で使用した. 潅流終了後, 単離した心室筋細胞は $\mathrm{KB}$ 溶液にいれ $4{ }^{\circ} \mathrm{C} て ゙$ 保 存した。

単離した心室筋細胞を, 倒立顕微鏡 $(\mathrm{TMS}, \mathrm{Ni}$ kon, Japan）のステージ上に固定したチャンバー のガラス底に置き, 高カリウム溶液で $\mathrm{KB}$ 溶液 を洗い流した後, 正常タイロード液で持続潅流し た. 実験はすべて $25^{\circ} \mathrm{Cで}$ 行った.

単一チャネル電流は細胞接着型パッチクランプ 法を用いて記録した ${ }^{11)}$. 保持電位から試験電位へ での脱分極パルス $(100 \mathrm{~ms}, 2 \mathrm{~Hz})$ をパーソナル コンピュータ（PC-9801 UV 2, NEC, Japan） を用いて与えた。

各溶液の組成は（mM）：正常タイロード溶液： $\mathrm{NaCl} 135 ; \mathrm{KCl} 5.4 ; \mathrm{CaCl}_{2} 1.8 ; \mathrm{MgCl}_{2} 1$;

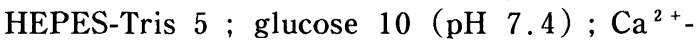
free 溶液：正常タイロード溶液より $\mathrm{Ca}^{2+}$ を除 いたもの； $\mathrm{KB}$ 溶液 : $\mathrm{KCl} 25$; タウリン 10 ; シュウ酸 10 ; グルタミン酸 $70 ; \mathrm{KH}_{2} \mathrm{PO}_{4} 10$; EGTA-Tris 0.5 ; HEPES-Tris 5 ; グルコース 10 (KOH の滴下で $\mathrm{pH} 7.4 ）$; 高カリウムタイロー ド溶液 : $\mathrm{Ca}^{2+}$-free タイロード溶液中の $\mathrm{NaCl}$ を等モルの $\mathrm{KCl}$ で置換. ピペット内溶液の組成 は $(\mathrm{mM}): \mathrm{BaCl}_{2} 50$ または100；塩化コリン 75または 0 ; HEPES-Tris 5 ; テトロドトキシン (三共) $0.03(\mathrm{pH} 7.4)$ とした. 塩酸イソプロテレ
ノール (Sigma, U.S.A.) アデノシン (Sigma U.S.A.) デオフィリン（Sigma U.S.A.）は正 常タイロード溶液に溶解し, 潅流液中に添加した.

PCM-データレコーダを用いてビデオテープに

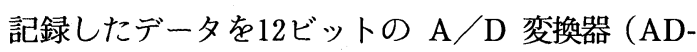
1240 インテリジント A $\mathrm{A}$ D コンバータ 日本 フェニックス）でデシタタル化した後，モニタ一上 に描出し, パーソナルコンピューターを用いて解 析した，基線および単一チャネル電流の大きさは 肉眼で調節した. 開状態と閉状態の間の移行は単 一チャネル電流の大きさの半分のレベルで判定し た. チャネル電流を含む掃引について, 単一チャ ネルの開確率を試験パルスの持続時間に対する全 開孔時間の比として計算した.データの比較には Student's unpaired $\mathrm{t}$ 検定を用いた.

\section{結果}

静止電位から静止電位 $+70 \sim 90 \mathrm{mV}$ への脱分極 パルス（パルス幅 $100 \mathrm{ms）} \mathrm{を} 2 \mathrm{~Hz}$ の頻度で反 復し, 単一 $\mathrm{Ca}^{2+}$ チャネル電流を記録してアデノ シン（Ado）の効果を調べた. 図-1亿典型的な記 録の 1 例を示す. チャネル電流を含む掃引（ノン ブランク）とチャネル電流を含まない掃引（ブラ ンク）の 2 つ型の掃引がそれぞれ群れをなして 記録されている. 図-1中にみられるように，ノン ブランク掃引の数は100nM-イソプロテレノール （ISO）の添加により著明に増加した．約 1,000 個 の掃引についてのノンブランク掃引の割合, すな わち利用可能性 (Ps) は0.29から0.78へ約 3 倍に 増加した. それに伴い, 約 1,000 個の掃引から得た 平均電流は.ISO によって約 3 倍に増大した. $0.1 \mathrm{mM}$-アデノシン（Ado）の添加はこの Ps お よび平均電流を明らかに減少させた．次いで心筋 のP 1 プリンレセプターを, 拮抗的に阻害するて とが知られている $0.1 \mathrm{mM}-$ デオフィリン ( $\mathrm{Teo})$ を添加したとてろ, 上記の Ado の抑制作用は部 分的に減弱され，ノンブランク掃引の数および平 均電流力増大した. Ado を洗い流すと Ps は Teo 非存在時とほほ同程度にまで回復した(図-1 B, E). 

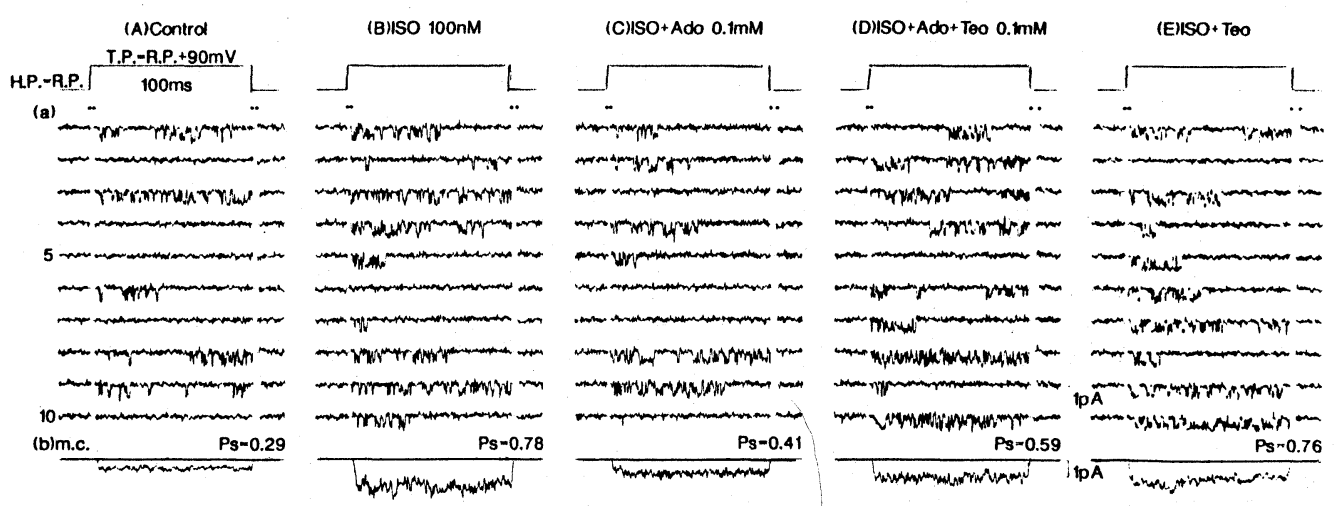

図-1 単一 Ca チャネル電流に対するイソプロテレノール (ISO)・アデノシン (Ado)・テオフィリン (Teo) の作用 静止電位から静止電位 $+90 \mathrm{mV}$ への, パルス幅 $100 \mathrm{~ms}$ の脱分極パルスを $2 \mathrm{~Hz}$ の頻度で約1000回繰り返した. $\mathrm{A}$, 対照 ; B, 100nM-ISO ; C, 0.1mM-Ado および ISO ; D, ISO, Ado および Teo；E, ISO および Teo. a : 単一 Ca チャ ネル電流の連続記録, フィルターの遮断周波数は $1 \mathrm{kHz} . \mathrm{b}$ : 全掃引から得た平均電流. Ps : チャネル電流を含む掃引の 全掃引に対する割合. ピペット内溶液は $100 \mathrm{mM}-\mathrm{Ba}^{2+}$ を含む.

したがって, Teo の増加作用はホスホジェステラー ゼの阻害によるものではない1).

平均電流の変化の要因である単一 $\mathrm{Ca}^{2+}$ チャネ ル特性の変化について統計的に解析した.

1. $\mathrm{Ca}^{2+}$ チャネル開確率・開孔時間・閉鎖時間 に対するアデノシンの効果

チャネル電流を含む掃引について，5つのパッ チより計算した開確率 $(\mathrm{Po})$ は対照時 $0.08 \pm 0.06$, ISO 添加時 $0.08 \pm 0.06$, Ado および ISO 添加時 $0.06 \pm 0.03$ であり, ISO・Ado のいずれによっ ても有意な影響をうけなかった. 図-2亿 ISO・A do・Teo の開孔時間ヒストグラムに対する効果 を示す. 対照時における開孔時間ヒスログラムの 分布は一次指数曲線で近似され，その時定数は 0.5 $\mathrm{ms}$ であった. 同様他他潅流液, すなわち ISO, ISO および Ado, ISO・Ado および Teo, ISO および Teo を含む潅流液中でも一次指数曲線で 近似され，その時定数は ISO 添加では $0.38 \mathrm{~ms}$, ISO および Ado 添加では $0.54 \mathrm{~ms}$, ISO ・ Ado および Teo 添加では $0.46 \mathrm{~ms}$, ISO および Teo 添加では $0.46 \mathrm{~ms}$ であった. また各条件下での平 均開孔時間はそれぞれ $0.65 \mathrm{~ms} \quad 0.63 \mathrm{~ms} \quad 0.62 \mathrm{~ms}$ $0.72 \mathrm{~ms} 0.70 \mathrm{~ms}$ であった. 開孔時間ヒストグラ ム・平均開孔時間とも ISO - Ado・Teo の潅流液

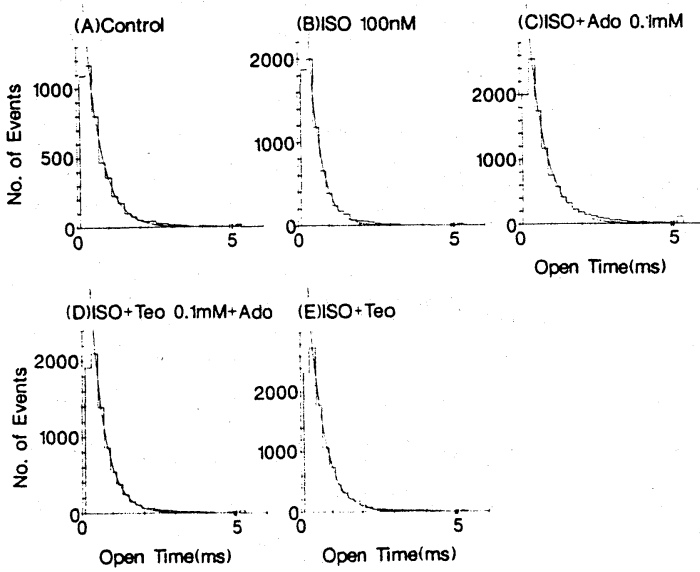

図-2 イソプロテレノール (ISO)・アデノシン (Ado) およびテオフィリン (Teo）の開孔時間ヒストグラ ムに対する効果

図-1に示した実験から得た結果を示す. 各ヒストグラムの縦軸 は事象の数, 横軸は持続時間を表す. 各ヒストグラムは一つの指 数曲線に適合し，その時定数は：A, 対照 $0.50 \mathrm{~ms} ; \mathrm{B}, 100 \mathrm{nM}$ ISO $0.38 \mathrm{~ms}$; C, ISO および O. $1 \mathrm{mM}$-Ado $0.54 \mathrm{~ms}$; D, ISO, Ado および 0.1mM-Teo $0.46 \mathrm{~ms} ;$ E, ISO および Teo 0.46 ms. Bin width は $0.2 \mathrm{~ms}$.

への添加によりほとんど影響されなかった。

図-3 は同じ実験における ISO・Ado・Teo の 閉鎖時間ヒストグラムに対する影響を示す．乙れ らの潅流液中での閉鎖時間ヒストグラムはいずれ 

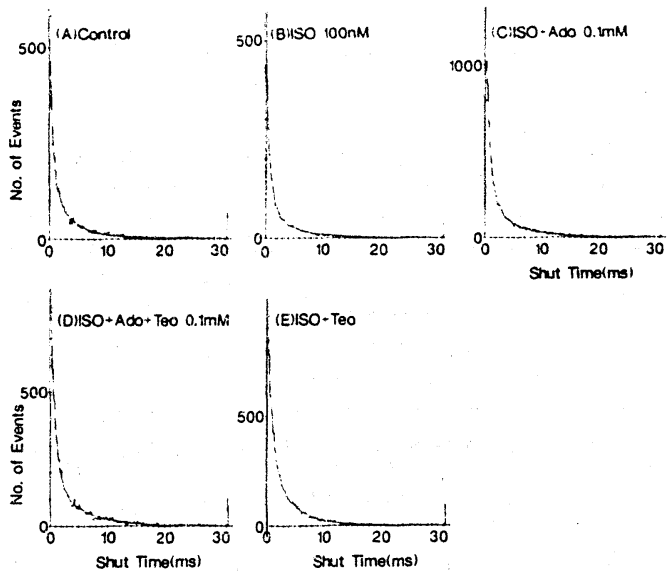

図-3 イソプロテノール (ISO)・アデノシン (Ado) およびテオフィリン (Teo）の閉鎖時間ヒストグラ ムに対する効果

図-1 亿示した実験結果から得た. 各ヒストグラムで縦軸は事象 の数, 横軸は持続時間を表す. 各ヒストグラムは二つの指数曲線 で近似される. A, 対照, $y=752 \exp -(x / 0.5)+140 \exp -(x /$ $4.0)$; B, 100nM-ISO, $y=551 \exp -(x / 0.7)+63 \exp -(x / 5.4)$ ; C, ISO および O. 1mM-Ado, $y=1520 \exp -(\mathrm{x} / 0.7)+219$ exp-(x/5.1)；D, ISO, Ado および 0.1mM-Teo, $y=881$ $\exp -(\mathrm{x} / 0.75)+185 \exp -(\mathrm{x} / 5.1) ; \mathrm{E}$, ISO および Teo, $\mathrm{y}=$ $974 \exp -(\mathrm{x} / 0.8)+322 \exp -(\mathrm{x} / 4.0)$. Bin width は $0.2 \mathrm{~ms}$.

もふたつの指数曲線で近似され，その速い成分の 時定数は $0.5 \mathrm{~ms}$ から $0.8 \mathrm{~ms}$ の範囲にあり, 遅 い成分の時定数は $4.0 \mathrm{~ms}$ から $5.4 \mathrm{~ms}$ の範囲に あった．平均閉鎖時間は $4.0 \mathrm{~ms}$ から $6.8 \mathrm{~ms}$ の 範囲にあり, 各溶液間で有意な差は認めなかった。

2. $\mathrm{Ca}^{2+}$ チャネル利用可能性に対するアデノシ ンの效果

図-4a に示したように全掃引に対するノンブ ランク掃引の割合を意味する利用可能性 (Ps) は, ISO 添加により $0.29 \pm 0.09$ (平均 \pm S.D. $\mathrm{n}=5$ ) 加ら $0.62 \pm 0.10(\mathrm{p}<0.01)$ 一増加し, Ado 添加 により $0.37 \pm 0.15(\mathrm{p}<0.05)$ に減少した。 この Ps の減少が Ado 添加による平均 $\mathrm{Ca}$ 電流減少 の理由と思われた。

Teo の存在下では ISO により増加した Ps の Ado 添加による減少は認められなかった(図-5a). Ps は ISO により $0.27 \pm 0.04$ から $0.71 \pm$ 0.08 に増加したが $(\mathrm{p}<0.01)$, Teo を添加して もほとんど変化しなかった $(0.71 \pm 0.09)$.さら

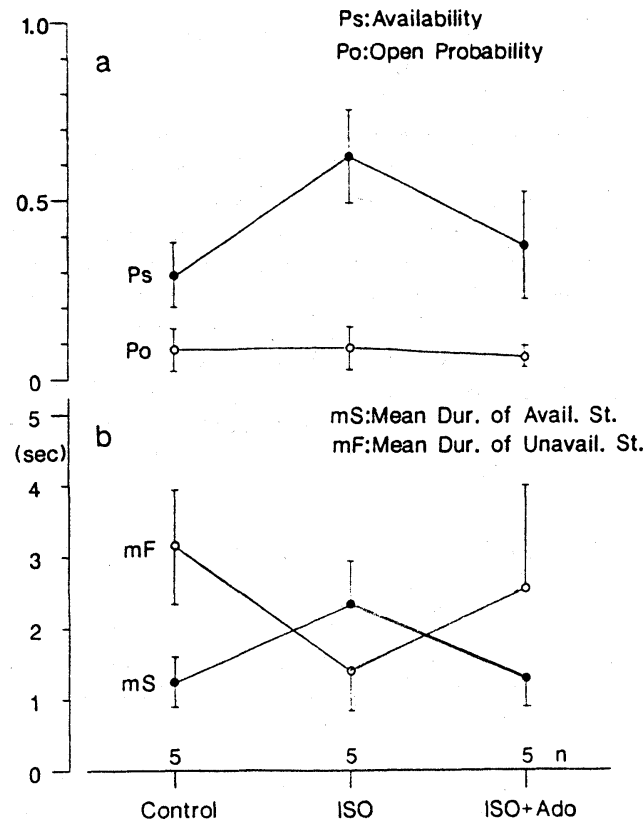

図-4 開確率 $(\mathrm{Po})$ ・利用可能性 $(\mathrm{Ps})$ ・利用可能状態 の平均持続時間 $(\mathrm{mS})$ - 非利用可能状態の平均持 続時間 (mF) に対するイソプロテレノール (ISO)・ アデノシン (Ado) の効果 (標本数は 5 個)

a，Po および Ps 亿対する 100nM-ISO および 0.1mM-Ado の効果. Ps は対照と ISO 添加の間 $(\mathbf{p}<0.01)$, ISO 添加 と ISO およびAdo 添加の間 $(\mathrm{p}<0.05)$ で有意差を認めた.

b, mS および $\mathrm{mF}$ に対する ISO および Ado の効果. $\mathrm{mS}$ は 対照と ISO 添加の間 $(\mathbf{p}<\mathbf{0 . 0 1})$, ISO 添加と ISO および Ado 添加の間 $(p<0.01)$ で, $\mathrm{mF}$ は対照と ISO 添加の間 $(\mathrm{p}<0.01)$ で有意差を認めた.

に続けて Ado を添加しても Ps は有意な変化を 示さなかった $(0.64 \pm 0.09)$. すなわち Ado の Ps を減少させる作用は, Teo により阻害された.

3 . 利用可能状態および非利用可能状態の持続 に対するアデノシンの効果

図-1亿示したように反復して脱分極パルスを 与えると,チャネル電流を含む掃引と含まぬ掃引 がぞの条件下でも群れをなして出現する傾向が認 められた。連続した掃引でブランク掃引が群れを なす程度と，ノンブランク掃引が群れをなす程度

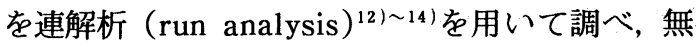
秩序性 $(\mathrm{Z})$ を次の式により求めた.

$$
\mathrm{Z}=-(\mathrm{R}-2 \mathrm{nPs}(1-\mathrm{Ps})) / 2 \sqrt{\mathrm{n}} \operatorname{Ps}(1-\mathrm{Ps})
$$




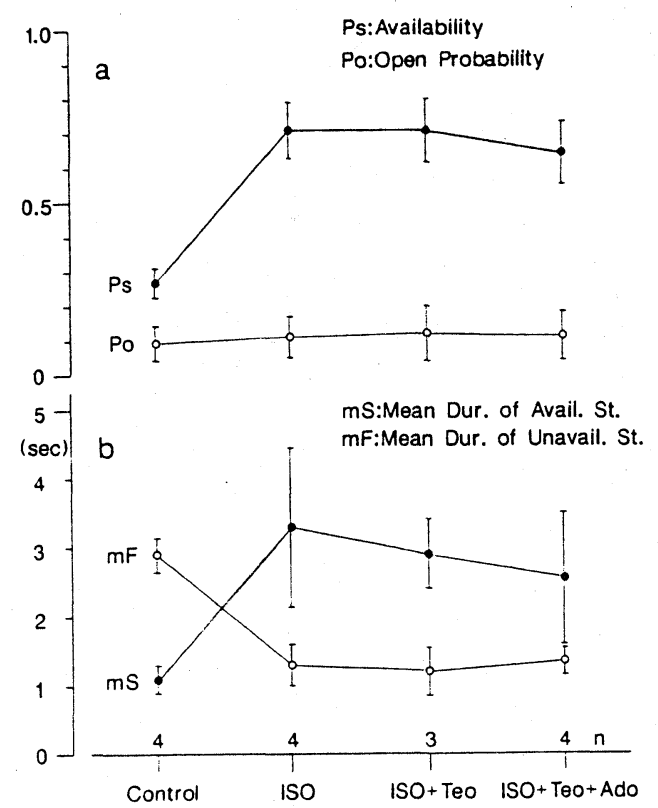

図-5 テオフィリン (Teo) 存在下における, 開確率 $(\mathrm{Po})$ ・利用可能性 $(\mathrm{Ps}) \cdot$ 利用可能状態の平均持 続時間 $(\mathrm{mS})$ - 非利用可能状態の平均持続時間 $(\mathrm{mF})$ に対する, イソプロテレノール (ISO)・ア デノシン (Ado) の効果. (標本数は図-1亿示した ものを含め 3 または 4 個)

対照と ISO 添加の間でのみ Ps $(p<0.01) \cdot \mathrm{mS}(\mathrm{p}<0.01) \cdot$ $\mathrm{mF}(\mathbf{p}<0.01)$ 亿有意差を認めた.

ただし $\mathrm{R}$ は連の数， $\mathrm{n}$ は全掃引数, Ps はノンブ ランク掃引数を $\mathrm{n}$ で除した商とする.

たとえば図-1 亿示した実験では, Z は対照18.9 ISO 添加時 17.1, ISO および Ado 添加時 18.1 であったごとく, Z は薬物の存在によらず正の大 きな值を示したことにより, ブランクおよびノン ブランクの起乙り方は無秩序ではないてとが示さ れた. またノンブランクの連, およびブランクの

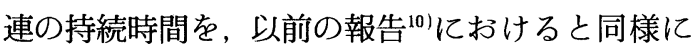
各連に含まれる掃引の数を数えて求めた. ISO • Ado の遅いゲート過程に対する効果を検討する 目的で, それらの添加前後の利用可能状態の平均 持続時間 $(\mathrm{mS})$,および非利用可能状態の平均持 続時間 (mF) を比較した. 図-4b に示したよう に $\mathrm{mS}$ は ISO 添加により $1.25 \pm 0.37 \mathrm{~s}$ （平
均 \pm S.D. $\mathrm{n}=5$ ) から $2.35 \pm 0.62 \mathrm{~s}$ 八増加し $(\mathrm{p}<0.01)$, ISO および Ado 添加で $1.31 \pm 0.41$ $\mathrm{s}$ に減少した $(\mathrm{p}<0.01) . \mathrm{MF}$ は ISO 添加で $3.16 \pm 0.78 \mathrm{~s}$ から $1.42 \pm 0.53 \mathrm{~s}$ 一減少し（p< $0.01)$, ISO および Ado 添加で $2.55 \pm 1.43 \mathrm{~s}$ に 増加した。

ISO・Ado による $\mathrm{mS} \cdot \mathrm{mF}$ の変化に対する Teo の効果を図- $5 \mathrm{~b}$ 亿示す. MS は ISO で $1.08 \pm$ $0.19 \mathrm{~s}$ から $3.31 \pm 1.16 \mathrm{~s}$ 一増加したが $(\mathrm{p}<0.01)$, さらに Teo および Ado を添加しても, それぞ れ $2.91 \pm 0.49 \mathrm{~s}, 2.57 \pm 0.93 \mathrm{~s}$ と有意な変化は示 さなかった. MF はISO で $2.91 \pm 0.25 \mathrm{~s}$ から $1.25 \pm 0.31 \mathrm{~s}$ 一減少し $(\mathrm{p}<0.01)$, さらに Teo および Ado を添加してもそれぞれ $1.20 \pm 0,35 \mathrm{~s}$ $1.34 \pm 0.22 \mathrm{~s}$ と有意な変化は示さなかった.

4. 単一 $\mathrm{Ca}^{2+}$ チャネルコンダクタンスに対す るアデノシンの効果

1000nM-BAY K8644 存在下で, 細胞接着型パッ チクランプ法により記録した多 $\mathrm{Ca}^{2+}$ チャネル電 流に対する ISO および Ado の効果を図- 6 亿示 す. 静止電位 $(\mathrm{RP})$ から $\mathrm{RP}+70 \mathrm{mV}$ への脱分 極パルス（パルス幅 $100 \mathrm{~ms}$ ) を $2 \mathrm{~Hz}$ の頻度で 反復して加えた. BAY K8644 は開孔時間をい ちじるしく延長したため, 開孔状態にある $\mathrm{Ca}^{2+}$ チャネルの数か明らかになった（図-6a). 単一 $\mathrm{Ca}^{2+}$ チャネル電流記録の重なりの数の変化を伴っ て平均電流は ISO で増加し (図-6B), Ado の 添加で減少した（図-6C). また図-7亿示すよう に BAY K8644 存在下で脱分極パルス中（静止 電位 $+70 \mathrm{mV}$ ) および直後 (静止電位) の単一 $\mathrm{Ca}^{2+}$ チャネル電流を記録すると, 単一 $\mathrm{Ca}^{2+}$ チャ ネルコンダクタンスを正確に測定するととが可能 であった.すなわち, 図-7右に示すように縦軸に 単一 $\mathrm{Ca}^{2+}$ チャネル電流の大きさ, 横軸に膜電位 をプロットし, その傾きとして単一 $\mathrm{Ca}^{2+}$ チャネ ルコンダクタンスを計算し求めた。 平均 $\mathrm{Ca}^{2+}$ 電 流には明らかな変化を認めたにもかかわらず，単 一 $\mathrm{Ca}^{2+}$ チャネルコンダクタンスは 23.7〜24.0 pS でISO・Ado のいずれによっても影響されな かった. 
(A)BAY K 1000nM $T P=R P+70 m V$
$H P=R P$

(a)

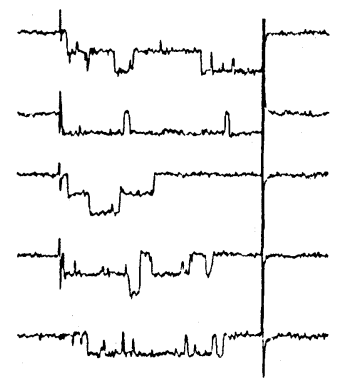

(b)m.c.

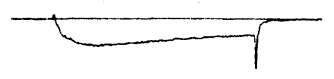

(B)BAY K+ISO 100nM (C)BAY K+ISO+Ado $0.1 \mathrm{mM}$
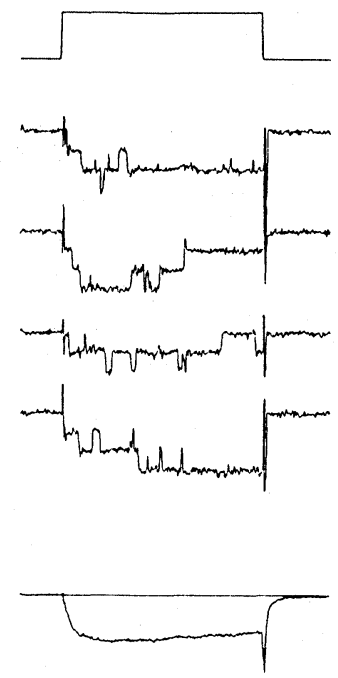
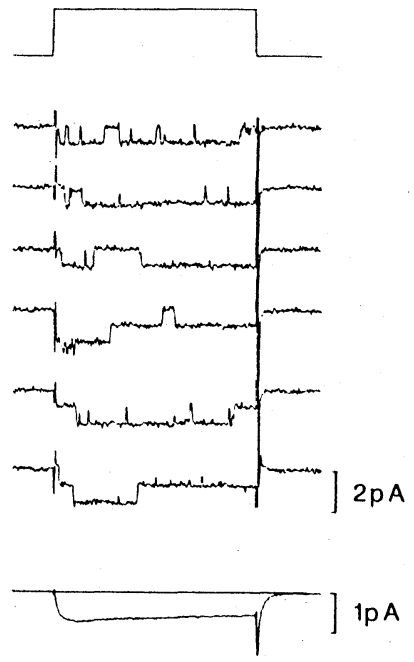

図- 6 BAY K8644 存在下におけるイソプロテレノール (ISO) とアデノシン (Ado) のCa チャネル電流に対する作用 1000nM-BAY K 8644 は潅流液中へ加えた. 静止電位から静止電位 $+70 \mathrm{mV}$ への, パルス幅 $100 \mathrm{~ms}$ の脱分極パルスを 2 $\mathrm{Hz}$ の頻度で反復した，ピペットは 50mM-Ba ${ }^{2+}$ を含むものを用いた. A, BA Y K8644； B，100nM-ISO および BAY $\mathrm{K} ; \mathrm{C}, 0.1 \mathrm{mM}-\mathrm{Ado}$, ISO および BAY K. a : 多 Ca チャネル電流記録, b : 平均電流. 平均電流は A では1169個の 掃引から, B および C では約560個の掃引から求めた.

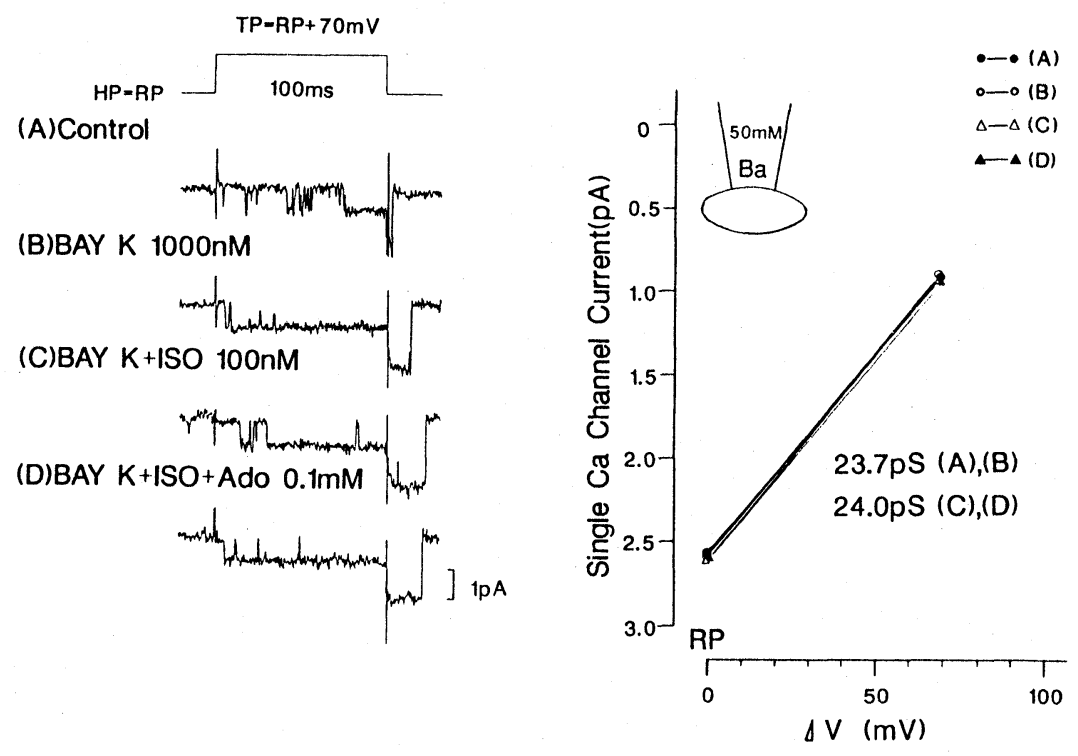

図-7 BAY K8644, イソプロテレノール (ISO)・アデノシン (Ado) の単一 Ca チャネルコンダクタンスに対する作用 単一 $\mathrm{Ca}$ チャネルコンダクタンスは, 脱分極パルス中および終了直後の単一 $\mathrm{Ca}$ チャネル電流の大きさから求めた. 左図：チャネル電流記録，A：対照, B ：1000nM-BAY K8644, C : 100nM-ISO および BAY K8644, D : ISO, 0.1mM-Ado および BAY K 8644. 右図 : 縦軸 : Ca チャネル電流の大きさ (pA), 横軸：膜電位 $(\mathrm{mV})$. 単一 $\mathrm{Ca}$ チャネルコンダクタンスは A, B : $23.7 \mathrm{pS}, \mathrm{C}, \mathrm{D} ： 24.0 \mathrm{pS}$. 


\section{考察}

近年パッチクランプ法 ${ }^{11}$ が発達した結果, 単一 $\mathrm{Ca}^{2+}$ チャネル電流を記録し種々の生理学的, なら びに臨床的に重要な要因による $\mathrm{Ca}^{2+}$ チャネルの 変化を直接的に検討することが可能になった。 そ して, すでに交感神経 $\beta$ 受容体刺激は $\mathrm{Ca}^{2+}$ チャ ネルの開確率 $(\mathrm{Po})$ および利用可能性 (Ps) の 両者を増大するととにより, $\mathrm{Ca}^{2+}$ チャネル電流を 増すことが報告されている ${ }^{15)}$. 本研究ではそのよ うな $\beta$ 受容体刺激下に, Ado によって生じる $\mathrm{Ca}^{2+}$ 電流減少時の $\mathrm{Ca}^{2+}$ チャネルの変化について 検討したところ, Ps の減少は認めたもののPoは ISO・Ado のいずれによってもほとんど変化しな かった.すなわち, $\mathrm{Ca}^{2+}$ チャネルの開孔時間およ び閉鎖時間の分布は，それぞれ単一および二重の 指数曲線に適合し, その時定数は ISO, ISO およ び Ado 添加の前後で実質上不変であった. ISO により Po の変化なしに Ps が増大したてとは,

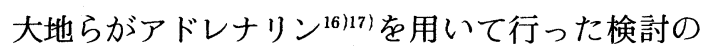
結果とよく一致する. てれらの結果から Adoに よる平均 $\mathrm{Ca}^{2+}$ 電流の減少, および巨視的 $\mathrm{Ca}^{2+}$ 電 流の減少 ${ }^{216)}$ は主として $\mathrm{Ca}^{2+}$ チャネル利用可能 性の低下によると結論された。

Ado による Ps の減少は, 利用可能状態の平 均持続時間.(mS) および非利用状態の平均持続 時間 $(\mathrm{mF})$ の変化によるものであった. Ado は 予め ISO により増大した $\mathrm{mS}$ を減少させる一方, ISO により減少した $\mathrm{mF}$ を ISO 使用前のレベル 近くにまで増大させた（図- $4 \mathrm{~b}$ ). Ps は $\mathrm{mS} /$ $(\mathrm{mS}+\mathrm{mF})$ によって与えられることから，ての Ado による $\mathrm{mS} \cdot \mathrm{mF}$ 両者の変化が利用可能性 (Ps) を減少させたと考えられた. 今回の研究で 用いたように過分極レベルで電位を保持した場合 には, 非利用可能状態の持続は単一指数関数とし て分布し, $\mathrm{mS}$ および $\mathrm{mF}$ の両者は広範囲の過 分極電位で一定であり, 不活性化過程はブランク 状態の発生にほとんどかかわらないととが示唆さ れている(10). Ado はいちじるしい過分極レベルに 電位を保持した場合には, $\mathrm{mS} \cdot \mathrm{mF}$ に反映され
る非電位依存性の遅いゲート過程を変化すること により, Ps を減少するように思われる.

細胞全体の $\mathrm{Ca}^{2+}$ 電流のゆらぎ解析によれば, 交感神経 $\beta$ 受容体刺激は単一 $\mathrm{Ca}^{2+}$ チャネルのコ ンダクタンスには影響しないとされている ${ }^{18)}$. 開 孔時間を著明に延長する BAY K $8644^{19}$ ) 存在下で は, 単一 $\mathrm{Ca}^{2+}$ チャネルコンダクタンスに対する 調節因子の影響を評価することができるが, 図-7 に示したように ISO・Ado ともに単一 $\mathrm{Ca}^{2+}$ チャ ネルコンダクタンスに影響しなかった。したがっ て, 単一 $\mathrm{Ca}^{2+}$ チャネルコンダクタンスは, Ado による $\mathrm{Ca}^{2+}$ 電流の減少に関与する要因の中に含 まれないと思われた。

パッチ内にあるチャネルは, ISO ・ Ado・Teo のいずれにも直接には接していないため, 平均電 流の増減は細胞内セカンドメッセンジャ一を介す るチャネルへの修飾によるものである. 最近, 生 化学的・電気生理学的研究によって心筋の $\mathrm{Ca}^{2+}$ チャネルの $\beta$ アドレナリン性修飾や, Ado による 修飾の信号伝達系が解明された ${ }^{2}$. $\beta$ 受容体刺激 剂は心筋細胞膜の $\beta$ 受容体と結合し, GTP 結合 蛋白質（Gs）を活性化してアデニールサイクラー ゼ（AC）の触媒作用活性を刺激する. サイクリッ ク AMP は, サイクリック AMP 依存性プロテ インカイネースとの相互作用により ${ }^{201} \mathrm{ATP}$ の終 末燐酸塩の $\mathrm{Ca}^{2+}$ チャネルを含む細胞内の種々の 蛋白への移動を起こす ${ }^{21)}$. Ado はメチルキサンチ ンによって競合的に阻害される P1 プリン受容体 を活性化し，もう一つの GTP 結合蛋白質 (Gi) を介して心筋の AC に働き, サイクリック AMP 蓄積の変化ならびに $\mathrm{Ca}^{2+}$ 流入の減少を生じる ${ }^{1}$. 上に示したように, Teo 存在下では ISO によっ て増加した $\mathrm{Ca}^{2+}$ チャネルの Ps は Ado により ほとんど変化せず，Teo で前処理した場合は利用 可能状態および非利用可能状態の持続 $(\mathrm{mS} \cdot \mathrm{mF})$ は, Ado によりあまり変化しなかった（図-5). これらの所見は Ado は心筋細胞膜の P 1 プリン 受容体を刺激し， Gi を介して AC に ISO の作 用を減弱するとの考えを支持する.すなわち, Ado は $\mathrm{Ca}^{2+}$ チャネルを脱燐酸化させてチャネルの 
利用可能性を減少するてとによって, ISO 亿よる $\mathrm{Ca}^{2+}$ チャネル電流の増加を抑制すると思われる.

\section{結語}

1.アデノシン (Ado) は, $\beta$-アゴニストによっ て増大した $\mathrm{Ca}^{2+}$ チャネル電流を $\beta$-アゴニスト存 在下で抑制した。

2. $\mathrm{Ca}^{2+}$ チャネル電流はBAY K8644存在下で も, 非存在下と同様に $\beta$-アゴニスト・Ado によ り修飾された。

3. Ado・ $\beta$-アゴニストは, 単一 $\mathrm{Ca}^{2+}$ チャネ ルコンダクタンスを変化させなかった.

4.テオフィリン（Teo）は, $\beta$-アゴニストに よって増大した $\mathrm{Ca}^{2+}$ チャネル電流を抑制する Ado の作用を抑制した.

5. $\beta$-アゴニスト・Ado・Teo は, チャネルの 平均開孔時間・開孔時間ヒストグラム・閉鎖時間 ヒストグラム・開確率 $(\mathrm{Po})$ に有意な影響を与え なかった。

6 . 利用可能性 $(\mathrm{Po})$ は, $\beta$-アゴニストでチャ ネル電流を含む掃引の連続数を増加し, Ado 添加 でこの連続数を減少するために有意に減少した。 Teo 存在下でも $\beta$-アゴニストの作用は影響を受 けなかった. しかし Teo 存在下では, Ado 添加 してもPs の有意な減少は認められなかった。

7. Ado の $\beta$-アゴニスト存在下での $\mathrm{Ca}^{2+}$ チャ ネル電流抑制は, 膜の P 1 -receptor（プリンレセ プター）を介し $\beta$ をアゴニストの遅いゲート過程 に対する効果を打ち消すことによると考えられた。

稿を終えるにあたり，終始で指導とで校閲を賜った大 地陸男教授に深甚なる謝意を表します。また，研究の機 会を与えて頂いた山口 洋教授,ならびに循環器内科学 教室一同の皆様に深く感謝いたします。さらに，パルス プログラム DAAD-12 system（Ver. 2.0）を提供し てくださいました明治乳業へルスサイエンス研究所生理 生化学研究室の吉井光信氏に深謝いたします。なお，て の結果の要旨は第53回日本循環器学会総会 (1989) にて 発表した ${ }^{22)}$.

\section{文献}

1 ) Buranstock G: Purinergic receptors in the heart. Supp. I, Circ. Res., 46 : I $\sim 175,1980$

2 ) Belardinelli L, Klockner U and Isenberg G : Modulation of potassium and calcium currents in atrial and nodal cells : ISOLATED ADU LT CARDIOMYOCYTES,Piper H.M. \& Isenberg G (ed.), CRC-press, vol. II : 155 180, 1989

3 ) Kurachi $Y$, Nakajima $T$ \& Sugimoto $T$ : On the mechanism of activation of muscarinic $\mathrm{K}$ channels by adenosine in isolated atrial cells : involvement of GTP-binding proteins, Pflugers Arch., $407: 264,1986$

4 ) James G Dobson, Jr.: Reduction by adenosine of the isoproterenol-induced increase in cyclic adenosine 3 ', $5^{\prime}$-monophosphate formation and glycogen phosphorylase activity in rat heart muscle. Circ Res., 43 : 785 792, 1978

5 ) Richard A Fenton and James G Dobson, Jr.: Adenosine and calcium alter adrenergicinduced intact heart protein phosphorylation. Am. J. Physiol., 246 : H559 565, 1984

6 ) Isenberg G, Belardinelli L : Ionic basis for the antagonism between adenosine and isoproterenol on isolated mammalian ventricular myocytes. Circ. Res., 55 : 309 325, 1984

7 ) Cerbai E, Klockner U, Isenberg G : Ca-antagonistic effects of adenosine in guinea pig atrial cells. Am. J. Physiol., 255 : H872 878, 1988

8 ) Schrader J, Baumann G, Gerlach E : Adenosine as inhibitor of myocardial effects of catecholamines. Pflugers Arch., 372 : 29, 1977

9 ) Burnstock G : A basis for distinguishing two types of purinergic receptor. In cell membrane receptors for drugs and hormones : A multidisciplinary Approach, Bolis L, Straub RW (ed.) New York, Raven Press, PP 107 108, 1978

10) Kawashima $Y$, Ochi $R$ : Voltage-dependent decrease in the availability of single calcium 
channels by nitrendipine in guinea-pig ventricular cells. Journal of Physiology., 402 : 219, 1988

11) Hamill OP, Marty A, Neher E, Sakmann B, and Sigworth FJ : Improved patch-clamp techniques for high-resolution current recording from cells and cell-free membranepatches : Pflugers Arch., 391 : 85, 1981

12) Horn R, Vandenberg CA, Lange K : Statistical analysis of single sodium channels. Effects of N-bromoacetamide. Biophys. J., 45 : $323 \sim 335,1984$

13) Standen NB, Stanfield PR and Ward TA : Properties of single potassium channels in vesicles formed from the sarcolemma of frog skeletal muscle., J. Physiol., $364: 339 \sim 358$, 1985

14) Cavalié A, Pelzer D, Trautwein W : Fast and slow gating behaviour of single calcium channels in cardiac cells : Relation to activation and inactivation of calcium current . Pflugers Arch., 406 : 241 258, 1986

15) Hescheler J, Trautwein W : Modulation of calcium currents of ventricular cells : ISOLAT ED ADULT CARDIOMYOCYTES, Piper H.M. \& Isenberg $\mathrm{G}$ (ed.), CRC-press, II : 129 154, 1989

16) Ochi R, Hino N, Niimi Y : Action of adre- naline and BAY K 8644 on the single calcium channels of cardiac muscle (in Japanese). Vas Sanguina., $8: 201,1984$

17) Ochi R, Hino N \& Okuyama H : Beta-Adrenergic modulation of the slow gating process of cardiac calcium channels. Japanese Heart Journal., suppl. $27: 51,1986$

18) Bean BP, Nowycky MC, Tsien RW : BetaAdrenergic modulation of calcium channels in frog ventricular heart cells. Nature, 307 : $371 \sim 375,1984$

19) Ochi R, Hino $N$ and Niimi $Y$ : Prolongation of calcium channel open time by the dihydropyridine derivative BAY K8644 in cardiac myocytes. Proc. Jpn. Acad., 60 : Ser B, 153, 1984

20) Kameyama M, Hofmann F, Trautwein W : On the mechanism of Beta-adrenergic regulation of the $\mathrm{Ca}$ channel in the guinea-pig heart. Pflugers Archiv., 405 : 285, 1985

21) Martin Rodbell : The role of hormone receptors and GTP-regulatory proteins in membrane transduction. Nature, $284: 17,1980$

22) Kato M, Yamaguchi H, Murakami H, Ochi $\mathrm{R}$ : Depression of calcium channel current by adenosine in guinea-pig ventricular cells. Jpn. Circ. J., $53: 1989$ 


\section{Summary}

\section{Mechanism of depression of calcium channel current by adenosine in guinea-pig ventricular cells}

The mechanism of the modulation of $\mathrm{Ca}$ current of cardiac muscle by adenosine was studied by recording the Ca-channel currents from cell-attached patches on isolated guinea-pig ventricular cells. The mean Ca-channel current from multi-channel Ba currents was augmented $2 \sim 3$ times by the application of $100 \mathrm{nM}$-isoproterenol (ISO) to the bath, and was diminished almost to the control level by the additon of $0.1 \mathrm{mM}$-adenosine. Adenosine has little affect the mean current in the absence of ISO. The adenosine-induced depression of the mean current was reduced by $0.1 \mathrm{mM}$-theophylline (TEO). The increase of the mean current by ISO and its reversal by adenosine occurred also in the presence of $1000 \mathrm{nM}-\mathrm{BAY} \mathrm{K} 8644$. In single-channel recordings, adenosine decreased the rate of current-containing sweeps (availability, Ps) in the presence of ISO. In five patches, Ps was increased by $100 \mathrm{nM}$-ISO from $0.29 \pm 0.09$ (mean \pm s.d.) to $0.62 \pm$ 0.13 and was decreased by the addition of $0.1 \mathrm{mM}$-adenosine to $0.37 \pm 0.15$. In these experiments the mean duration of the available state $(\mathrm{mS})$ was prolonged by ISO and shortened by adenosine (control $1.3 \pm 0.4 \mathrm{~s}$; ISO $2.4 \pm 0.6 \mathrm{~s}$; ISO and Ado $1.3 \pm$ $0.4 \mathrm{~s})$, while the mean duration of the unavailable state $(\mathrm{mF})$ was shortened by ISO and prolonged by adenosine (control $3.2 \pm 0.8 \mathrm{~s}$; ISO $1.4 \pm 0.5 \mathrm{~s}$; ISO and adenosine $2.6 \pm 1.4 \mathrm{~s}$ ). It was not accompanied by significant changes in the open time, the close time, the open state probability or the single-channel conductance. We conclude that the decrease in the availability of the Ca-channel is responsible for the adenosineinduced inhibition of the Ca current.

Key words : calcium channel, adenosine, cardiac muscle

MaKoto KATO, M.D.

Division of Cardiology, Depertment of Internal

Medicine, Juntendo University School of Medicine, Tokyo, Japan 